\title{
Ginkgo leaf sign and subcutaneous emphysema
}

\author{
Mohan Kumar H, Kundan Mishra, Arihant Jain, Navneet Sharma
}

Department of Internal Medicine, Post Graduate Institute of Medical Education and Research, Chandigarh, India

\section{Correspondence to Dr Mohan Kumar H, monu8501@gmail.com}

Accepted 13 November 2018

\section{DESCRIPTION}

A 40-year-old man presented with a history of altered sensorium and shortness of breath following deliberate unknown substance consumption. On examination, blood pressure was $100 / 60 \mathrm{~mm} \mathrm{Hg}$, pulse rate $64 / \mathrm{min}$ with excessive sweating, hypersalivation, bilateral pin-point pupil and urinary incontinence. Chest examination had excessive secretions with investigations showing red cell cholinesterase level of $143 \mathrm{IU} / \mathrm{L}$ (normal range 9572-150 $31 \mathrm{IU} / \mathrm{L}$ ).

The patient was managed in the line of anticholinesterase poisoning with atropine and other supportive care, gradually he required intubation followed by mechanical ventilation for respiratory distress. Six hours after intubation, the patient developed subcutaneous emphysema extending from the neck to the anterior abdominal wall. Chest X-ray was performed to confirm the position of endotracheal tube showed air in subcutaneous tissues around the neck and axilla with radiolucent striations around the individual fibres of bilateral pectoralis major muscles (Gingko leaf sign) (figure 1). The patient underwent tracheostomy, and improved over 1 week and discharged.

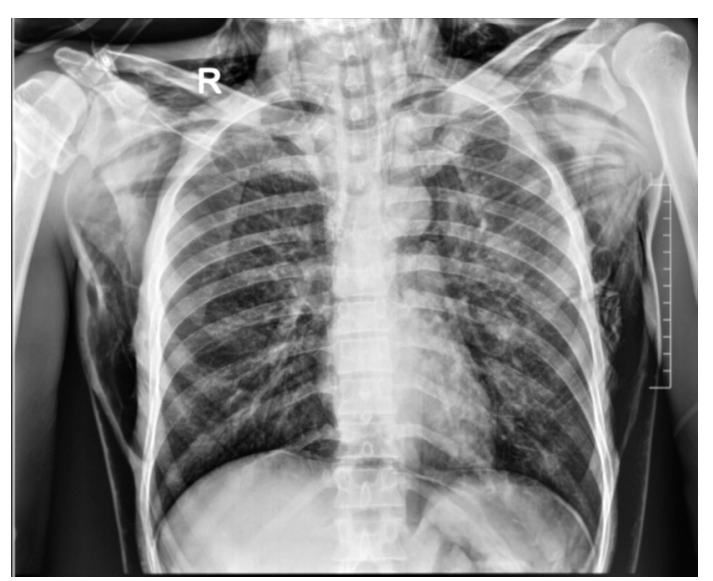

Figure 1 Chest X-ray showing air in subcutaneous tissues around the neck and axilla with radiolucent striations around the individual fibres of bilateral pectoralis major muscles giving the appearance of the venous system of Ginkgo leaf or 'Ginkgo Leaf sign'.
Subcutaneous emphysema secondary to tracheal injury following endotracheal intubation is rare $(0.005 \%))^{1}$ The patient with extensive subcutaneous emphysema presented with compression symptoms of the airway and venous system. Diagnosis is clinical and done by palpating crepitus in the involved area. Chest radiograph shows air in the soft tissues and air around the pectoralis major create radiolucent striations outlining the individual fibre and gives the appearance of the venous system of Ginkgo leaf known as Ginkgo leaf sign. ${ }^{2}$ Bronchoscopic examination renders valuable information in management of tracheal ruptures. Subcutaneous emphysema is managed conservatively unless there are compression symptoms or extension into mediastinum or pleura which warrants surgical drainage. ${ }^{3}$

\section{Learning points}

Tracheal injury is a rare complication of endotracheal intubation and timely intervention can prevent morbidity and mortality.

- This chest radiograph shows the classical appearance of 'Ginkgo leaf' sign.

- All cases of subcutaneous emphysema do not require active intervention but bronchoscopy helps in management and follow-up.

Contributors $\mathrm{MKH}, \mathrm{AJ}$ and NS were involved in primary case management. MKH and KM wrote the manuscript with input from all authors. AJ and NS conceived the study and were in charge of overall direction and planning.

Funding The authors have not declared a specific grant for this research from any funding agency in the public, commercial or not-for-profit sectors.

Competing interests None declared.

Patient consent Obtained.

Provenance and peer review Not commissioned; externally peer reviewed.

\section{REFERENCES}

$1 \mathrm{Lim} H$, Kim JH, Kim D, et al. Tracheal rupture after endotracheal intubation - a report of three cases. Korean J Anesthesiol 2012;62:277.

2 Ho ML, Gutierrez FR. Chest radiography in thoracic polytrauma. AJR Am J Roentgenol 2009;192:599-612.

3 Ovári A, Just T, Dommerich S, et al. Conservative management of post-intubation tracheal tears-report of three cases. J Thorac Dis 2014;6:E85-91. 
Copyright 2018 BMJ Publishing Group. All rights reserved. For permission to reuse any of this content visit https://www.bmj.com/company/products-services/rights-and-licensing/permissions/

BMJ Case Report Fellows may re-use this article for personal use and teaching without any further permission.

Become a Fellow of BMJ Case Reports today and you can:

- Submit as many cases as you like

- Enjoy fast sympathetic peer review and rapid publication of accepted articles

Access all the published articles

Re-use any of the published material for personal use and teaching without further permission

For information on Institutional Fellowships contact consortiasales@bmjgroup.com

Visit casereports.bmj.com for more articles like this and to become a Fellow 